\title{
Penerapan Algoritma LZ77 dan Algoritma Difference Coding Untuk Memperkecil Ukuran pada Citra Satelite Geoeye
}

\author{
Amanda Pratama, Muhammad Syahrizal \\ Program Studi Teknik Informatika, STMIK Budi Darma, Medan, Indonesia \\ Email: ${ }^{1}$ amandapratama2905@gmail.com \\ Submitted 31-03-2020; Accepted 20-04-2020; Published 26-04-2020
}

\begin{abstract}
Abstrak
Citra satelit geoeye merupakan salah satu citra satelit yang memiliki resolusi yang tinggi dan mulai populer dalam beberapa tahun terakhir ini. Sebagasi salah satu citra satelit yang mendunia, sudah jelas citra satelit ini menawarkan hal yang mampu memukau siapa pun penggunanya, citra satelit ini menawarkan citra permukaan bumi dengan tingkat kedetilan yang bisa dibilang luar biasa, serta tingkat akurasi setelah dibandingkan dengan citra satelit yang memiliki resolusi tinggi lainnya.
\end{abstract}

Kata Kunci: Algoritma Lz77, Difference Coding, Citra Satelite Geoeye

\begin{abstract}
Geoeye satellite imagery is one of the satellite images that has a high resolution and is gaining in popularity in recent years. As one of the global satellite imagery, it is clear that this satellite image offers something that can amaze anyone of its users, this satellite image offers an earth surface image with a level of detail that can be considered extraordinary, and the level of accuracy after compared to satellite imagery that has high resolution the other.
\end{abstract}

Keywords: Lz77 Algorithm, Difference Coding, Geoeye Satellite Image

\section{PENDAHULUAN}

Citra satelit geoeye merupakan salah satu citra satelit yang memiliki resolusi yang tinggi dan mulai populer dalam beberapa tahun terakhir ini. Sebagasi salah satu citra satelit yang mendunia, sudah jelas citra satelit ini menawarkan hal yang mampu memukau siapa pun penggunanya, citra satelit ini menawarkan citra permukaan bumi dengan tingkat kedetilan yang bisa dibilang luar biasa, serta tingkat akurasi setelah dibandingkan dengan citra satelit yang memiliki resolusi tinggi lainnya.

Kompresi adalah proses mengubah data menjadi sekumpulan kode untuk menghemat tempat penyimpanan dengan atau tanpa mengurangi kualitas dari citra serta mempercepat waktu transmisi data. Pada penggunaannya, ada beberapa faktor yang sering menjadi pertimbangan dalam memilih suatu metode kompresi, yaitu kecepatan kompresi, sumber daya yang dibutuhkan (memori, kecepatan PC), ukuran file hasil kompresi serta kompleksitas algoritma, karena pada intinya tidak setiap metode kompresi sesuai untuk semua jenis file gambar.

Adapun permasalahan pada gambar citra satelit geoeye yang mana pada saat proses pengiriman gambar melalui email sering terjadi kegagalan atau tidak dapat dikirim dikarenakan ukuran data pada saat proses pengiriman pada gambar citra satelit mempunyai ukuran data yang cukup besar karena itu maka perlu dilakukan teknik kompresi, yang mana nantinya dapat menghasilkan data yang lebih kecil untuk menghemat memori dannantinya secara otomatis memori dapat menyimpan data lebih banyak lagi.

Tujuan dari kompresi terhadap citra digital ini adalah untuk mengurangi redudansi dari data-data yang terdapat dalam citra sehingga dapat disimpan atau ditransmisikan secara efisien. Masalah inilah yang menyebabkan munculnya kebutuhan akan kompresi citra tanpa harus mengurangi informasi yang tersimpan didalam citra tersebut lossless [1].

\section{METODE PENELITIAN}

\subsection{Kompresi Citra}

Kompresi citra adalah proses pemampatan citra yang bertujuan untuk mengurangi duplikasi data pada citra sehingga memory yang digunakan untuk merepresentasikancitra menjadi lebih sedikit dari pada representasi citra sebelumnya [1].

\subsection{Algoritma Lz77}

Algoritma Lz77 merupakan salah satu metode untuk melakukan kompresi data yang dibuat oleh Abrahamem Lempel dan Jacob Ziv pada tahun 1977. Metode kompresi ini dilakukan dengan pencarian kedepan dan belakang, biasa disebut search buffer dan look ahead buffer.

Dalam blok dikompresi, jika serangkaian duplikat byte adalah melihat (string berulang), maka referensi belakang dimasukkan, menghubungkan ke lokasi sebelumnya yang identik string, bukan. Sebuah pertandingan di kodekan ke string sebelumnya terdiri dari panjang (3-258 bytes) dan jarak (1 -32.768bytes). Relatif back-referensi dapat dibuat di sejumlah blok, asalkan jarak muncul dalam $32 \mathrm{~Kb}$ terakhir dari data terkompresi decode (disebut sliding window) [2]. Komponen yang dibutuhkan dalam algoritma kompresi ini adalah:

1. Input Stream = Kumpulan karakter yang akan dikompresi.

2. Character $=$ Elemen dasar pada input stream.

3. Look-ahead buffer = Kumpulan karakter yang belum dikompresi, setelah token.

4. Search buffer $=$ Kumpulan karakter yang telah di kompresi, sebelum token. 


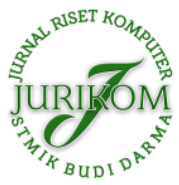

5. $\quad$ Token $=$ Berisi kumpulan dari (offset, length, dan next symbol).

\subsection{Algoritma Difference Coding}

Pada metode Difference Coding kompresi file yang berbentuk *jpg dilakukan dengan mengurangi nilai pixel dengan nilai pixel sebelumnya. Ada dua tahap utama kompresi dengan metode Difference Coding untuk nilai pixel, yaitu difference dan coding. difference adalah pengurangan nilai pixel dengan nilai pixel sebelumnya ke dalam nilai eksak. Coding adalah menuliskan kode yang berisi nilai pixel dengan hasil pengurangannya.Prinsip kerja metode Difference Coding adalah mengurangi nilai pixel dengan nilai pixel sebelumnya.Untuk pixel pada posisi (Index) ke -0 tetap dipertahankan [4].

Sebagai contoh diberikan sampel pixel sebagai berikut: 40404040404343100102102102 adalah 11 byte x 8 bit adalah 88 bit. Data difference adalah selisih data ke dua dengan pertama yaitu $40-40 \rightarrow 0$. Data pertama dilakukan coding yaitu 40 ditambah hasil selisih menjadi: 40 0. Selanjutnya lakukan cara difference untuk data 3, 4 dan seterusnya sehingga menghasilkan kode hasil kompresi sebagai berikut: 40000030572000 adalah 4 byte dan 8 bit yaitu 4 byte adalah $4 x$ 8 bit $=32$ bit. Jadi ada 36 bit hasil kompresi.

\section{HASIL DAN PEMBAHASAN}

Kompresi citra bertujuan untuk mengetahui cara kerja dan tingkat efisiens pada metode yang akan digunakan saat kompresi citra tersebut. Yang mana nantinya proses kompresi dengan menggunakan metode Lz77 dan algoritma difference codingdalam mengkompresi, karna dalam kompresi ini menyatukan dua metode yang berbeda yaitu pada kompresi pertama digunakan metode $L z 77$, dan akan dikompresi lagidengan menggunakan algoritma difference coding.

\subsection{Penerapan Algoritma LZ77 Pada Citra Geoeye}

Pada Penelitian ini akan diuraikan proses kompresi untuk memperkecil ukuran citra dilakukan dengan menerapkan saat dilakukannya proses kompresi. Disini penulis membuat sample dengan citra grayscale. Berikut contoh sebuah citra grayscale yang memiliki resolusi 96 dpi dan berukuran 855x 596 pixel yang besar ukuran filenya 806,304 Kbyte.Berikut ini sample gambar citra grayscale satelite geoeye:

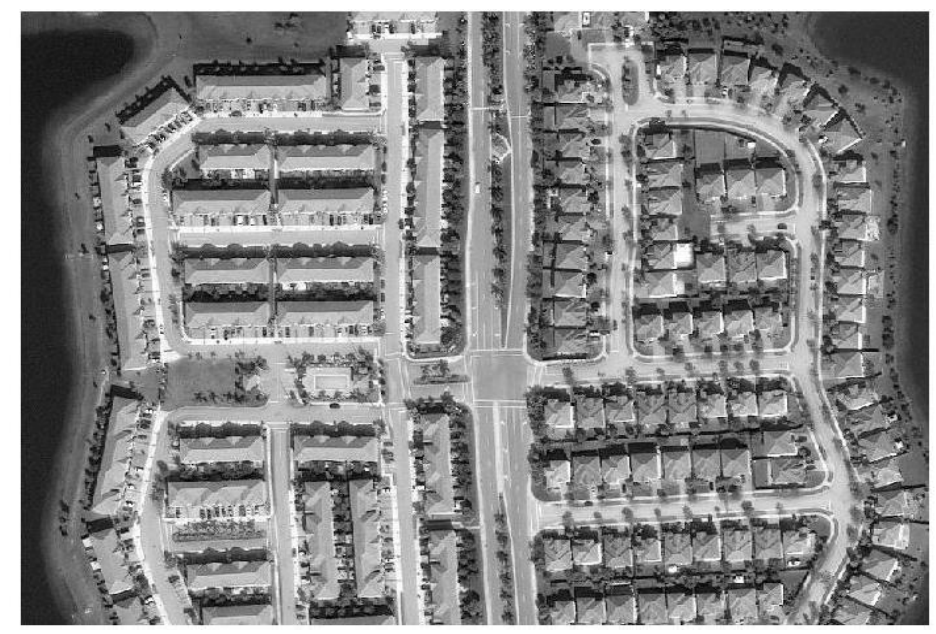

Gambar 1. Citra grayscale satelite geoeye

Dimana ukuran citra resolusi 855 x 596 pixel akan diambil sampelnya menjadi 4x4 pixel. Berdasarkan citra di atas di asumsikan nilai piksel dari citra tersebut setelah diperkecil resolusinya menjadi $4 \times 4$ pixel sehingga didapat nilai pikselnya menjadi seperti berikut ini

Tabel 1. Tabel Citra Grayscale 4 x 4

\begin{tabular}{llll}
\hline 2 & 4 & 4 & 5 \\
2 & 3 & 4 & 5 \\
3 & 2 & 3 & 3 \\
5 & 5 & 5 & 5 \\
\hline
\end{tabular}

Matriks tersebut akan dibaca oleh search buffer dari kanan ke kiri seakan membentuk jendela yang bergerak (sliding windows) dari kanan ke kiri. Data matriks yang akan di kelompokkan adalah "244523453233555 5”. Kolom sebelah kiri disebut search buffer dan kolom sebelah kanan disebut look-ahead buffer.

MetodeKompresi LZ77 merupakan metode kompresi Sliding Windows Compression, struktur data yang berupa text windows akan dibagi menjadi 2 bagian, terdiri dari teks yang sudah dikodekan (history buffer) dan bagian lain dari teks yang akan dikodekan (lookahead buffer).Berikut ini adalah langkah-langkah kompresi Menggunakan algoritma Lz77 :

1. Hitung jumlah karakter yang ada di lookahead buffer. 
2. Setelah dihitung buatlah index yang ada dihistory buffer.

3. Mencari nilai yang sama dari lookahead buffer ke history buffer.

2. Masukkan nilai lookahead buffer dan history buffer ke output.

3. Ulangi langkah 1 dan 2 sampai karakter yang ada di lookahead buffer habis.

Tabel 2. Algoritma LZ77

\begin{tabular}{rll}
\hline Search Buffer & \multicolumn{1}{c}{$\begin{array}{c}\text { Look-Ahead } \\
\text { Buffer }\end{array}$} & Output \\
2 & 2445234532335550 & $(0,0, " 2)$, \\
24 & 445234532335555 & $(0,0, " 4)$, \\
2445 & 25234532335555 & $(1,1, " 2)$, \\
244523 & 453233355555 & $(4,1, " 4)$, \\
244523453 & 2335555 & $(5,4,, 2)$, \\
244523453233 & 5555 & $(9,4,, 5)$, \\
24452345323355 & 55 & $(9,2, " 5)$, \\
2445234532335550 & & $(11,4, " 5)$, \\
\hline
\end{tabular}

Setelah dikelompokan maka matriks diatas dengan menggunakan algoritma LZ77 maka didapat token dari algoritma tersebut seperti berikut :

$(0,0, " 2 ")$

$(0,0, " 4 ")$

$(1,1, " 2 ")$

$(4,1, " 4 ")$

$(5,4, " 2 ")$

$(9,4, ", 5 ")$

$(9,2, " 5 ")$

$(11,4, " 5 ")$

$(0,0, " \varnothing ")$

Berikut ini hasil dari pengelompokan dengan menggunakan algoritma Lz77 adalah sebagai berikut :"0 0200411 2414542945925114500 ǿ" file ini memiliki ukuran sebesar 28 Byteyang berarti memori membutuhkan tempat penyimpanan sebesar $28 \times 8$ bit $=224$ bit.

Ukuran citra sebelum dikompresi $=16$ byte atau 128 bit

Ukuran citra setelah dikompresi $=224$ bit

Rasiopemampatan $=100-($ hasil kompresi / ukuran citra semula) $\mathrm{x} 100 \%$

Rasio pemampatan $=100-(224 / 128) \times 100 \%$

Rasio pemampatan $=100-(1.75) \times 100 \%$

Rasio pemampatan $=100-175$

Rasio pemampatan $=-75 \%$ artinya $-75 \%$ dari citra semula telah dimampatkan.

\subsection{Penerapan Difference Coding Pada Citra Geoeye}

Setelah penulis mendapakan hasil kompresi metode Lz77 selanjutnya penulis melakukan kompresi menggunakan metode Difference Coding. Prinsip kerja metode Difference Coding adalahAda dua tahap utama kompresi dengan metode Difference Coding untuk nilai pixel, yaitu difference dan coding. difference adalah pengurangan nilai pixel dengan nilai pixel sebelumnya ke dalam nilai eksak. Coding adalah menuliskan kode yang berisi nilai pixel dengan hasil pengurangannya. Prinsip kerja metode Difference Coding adalah mengurangi nilai pixel dengan nilai pixel sebelumnya.Untuk pixel pada posisi (Index) ke -0 tetap dipertahankan. Langkah langkah untuk difference coding sebagai berikut :

1. Baca nilai sampel dari awal sampai akhir.

2. Bandingkan data sampel pertama dengan kedua.

3. Hitung selisihnya.

4. Coding data sebagai nilai sampel dengan selisihnya.

5. Ulangi langkah 2 sampai 4 sampai sampel habis.

6. Simpan hasil coding $\rightarrow$ data terkompresi.

Untuk menggetahui cara kerja kompresi Difference Coding, penulis mengimplementasikan dengan menggunakan data hasil kompresi Lz77, maka seperti dibawah inilah data yang akan di kompresi :

Sampel pixel"0 02004112414542945925114500 " file ini memiliki ukuran sebesar 28 byte atau sama dengan 224 bit.

Selisih data ke dua dengan pertama yaitu $0-0=0$ dan pada data pertama dilakukan coding yaitu 0 ditambah hasil selisih menjadi: 0 2, selanjutnya lakukan cara difference untuk data 3, 4 dan seterusnya sehingga menghasilkan kode hasil kompresi sebagai berikut: “0 2204301233112751473673150 "sebanyak 26 byteatau 208 bit.

Ukuran citra hasil kompresi Lz77 $=28 \times 8$ bit $=224$ bit

Ukuran citra hasil difference coding $=26 \times 8$ bit $=208$ bit 
Rasio $=100-($ hasil kompresiLz77/ hasil kompresi Difference coding) $\times 100 \%$

Rasio $=100-(224 / 208) \times 100 \%$

Rasio $=100-108$

Rasio $=-8 \%$ artinya $-8 \%$ dari citra semula telahdimampatkan.

Keterangan:

1. Metode Lz77 cocok untuk kompresi citra yg memiliki deretan nilai pixel yang sama dalam satu baris.

2. Hasil kompresi metode Lz77 akan menjadi lebih banyak jika deretan nilai pixel berbeda-beda dalam satu baris.

\section{KESIMPULAN}

Berdasarkan hasil analisa pada bab-bab sebelumnya maka penulis dapat menarik kesimpulan yang mana kesimpulan tersebut nanti dapat kiranya berguna bagi pembaca, sehingga penulisan ini dapat berguna dan bermanfaat. Adapun kesimpulankesimpulan yang penulis berikan adalah sebagai berikut:

1. Dalam proses menentukan ukuran pixel pada citra geoeye dengan menggunakan aplikasi Matlab 2013 yang mana setelah didapat jumlah pixelnya penulis menggunakan sample 4x4 pixel untuk diterapkan pada metode Lz77 dan Difference Coding.

2. Cara kerja metode Lz77 dalam mengkompresi adalah semakin besar history buffer dan lookahead buffer akan membuat banyak pola pixel yang sama pada gambar yang akan berpengaruhi terhadap kecil dan besarnya ukuran hasil kompresi. Untuk cara kerja algoritma Difference coding dalam mengkompresi citra dengan cara mengurangi nilai pixel dengan nilai pixel sebelumnya Ada dua tahap utama kompresi dengan metode Difference Coding untuk nilai pixel, yaitu difference dan coding. difference adalah pengurangan nilai pixel dengan nilai pixel sebelumnya ke dalam nilai eksak. Coding adalah menuliskan kode yang berisi nilai pixel dengan hasil pengurangannya.

\section{REFERENCES}

[1] Sutojo. T. Mulyanto. E, "Kompresi Citra," in Pengolahan Citra Digital, Yogyakarta, Penerbit Andi, 2009, pp. 165-168.

[2] Darma Putra, "Pengolaha Citra," Yogyakarta, Andi, 2010, p. 290.

[3] P. Barita, "A Comparative Study of Image Format Compression Deflate Algorithms," A Comparative Study of Image Format Compression Deflate Algorithms, vol. 6, no. 12, 2017.

[4] T. Mizwar, G. L. Ginting, Mesran, A. Fau, S. Aripin, and D. Siregar, "IMPLEMENTASI ALGORITMA J-BIT ENCODING PADA KOMPRESI FILE TEKS,” KOMIK (Konferensi Nas. Teknol. Inf. dan Komputer), vol. 1, no. 1, pp. 232-236, 2017.

[5] M. R. Irliansyah, S. D. Nasution, and K. Ulfa, "Penerapan Metode Deflate Dan Algoritma Goldbach Codes Dalam Kompresi File Teks," KOMIK (Konferensi Nas. Teknol. Inf. dan Komputer), vol. 1, no. 1, pp. 186-189, 2017. 